\title{
Development of PCR Primers to Identify Fusarium oxysporum f. sp. fragariae
}

H. Suga, Life Science Research Center, Gifu University, Gifu 501-1193, Japan; Y. Hirayama, Nara Prefectural Experiment Station, Nara 634-0813, Japan; M. Morishima, Tochigi Prefectural Agricultural Experiment Station, Tochigi 320-0002 Japan; T. Suzuki, Chiba Prefectural Agriculture and Forestry Research Center, Chiba 266-0006 Japan; K. Kageyama, River Basin Research Center, Gifu University, 501-1193, Gifu, Japan; and M. Hyakumachi, Faculty of Applied Biological Science, Gifu University, 501-1193, Gifu, Japan

\begin{abstract}
Suga, H., Hirayama, Y., Morishima, M., Suzuki, T., Kageyama, K., and Hyakumachi, M. 2013. Development of PCR primers to identify Fusarium oxysporum f. sp. fragariae. Plant Dis. 97:619-625.

Fusarium oxysporum f. sp. fragariae is a fungal pathogen causing Fusarium wilt on strawberry. Polymerase chain reaction (PCR) primers that can discriminate $F$. oxysporum f. sp. fragariae from nonpathogenic F. oxysporum would greatly assist pathogen identification. In order to develop a molecular diagnostic tool for this pathogen, transposable elements in the pathogen were characterized and used for designing a specific set of PCR primers. Portions of the transposable elements Fot3, Han, Hop, Hornet1, and Skippy were detected in all 33 strains of F. oxysporum f. sp. fragariae tested by PCR, whereas Foxy was detected in 32 strains and Impala sequences were detected in 30 strains. Two types of sequences were detected for Hop, two types for Impala,

and three types for Skippy. The genomic region between Han and Skippy was amplified by an inter-retrotransposon amplified polymorphism technique, and PCR primers (FofraF and FofraR) to specifically identify $F$. oxysporum f. sp. fragariae were designed from this region. The developed PCR primers discriminated $F$. oxysporum f. sp. fragariae strains from nonpathogenic $F$. oxysporum strains and five other formae speciales. Conidia of $F$. oxysporum f. sp. fragariae could be detected in brown lowland-type soil by PCR using the primers. After preculturing the soil sample on FoG2 medium, $1 \times 10^{2}$ conidia/g of soil could be detected; without preculturing, $1 \times 10^{3}$ conidia/g of soil were detected.
\end{abstract}

Strawberry (Fragariae $\times$ ananassa Duch.) is an economically important crop grown worldwide. However, most of the strawberry cultivars are highly susceptible to several destructive and economically important soilborne diseases such as Phytophthora rot, Verticillium wilt, and Fusarium wilt. Fusarium wilt was first reported in Australia in 1965 (25) and has since been reported in Japan (14), Korea (16), China (26), Spain (1), and the United States (10). The causal agent, Fusarium oxysporum f. sp. fragariae Winks \& Y.N. Williams, is a haploid mitosporic fungus and is difficult to control because the pathogen survives as chlamidospores in soil for many years. Early detection and diagnosis of the pathogen in plants and soils is essential for development of an effective disease control strategy.

F. oxysporum is distributed in soils worldwide and causes vascular wilt or root rot disease in over 100 plant species. However, hosts for individual strains of this pathogen are confined to a single or a few plant species. Therefore, F. oxysporum is subdivided into formae speciales based on host specificity. Furthermore, some formae speciales include strains that only cause disease on certain varieties of a plant species and are subdivided into races. In addition, pathogenic strains of $F$. oxysporum are morphologically indistinguishable from nonpathogenic strains Selective media are useful for isolating Fusarium spp. from plants, soils, and air. However, species identification is quite difficult using only colony morphology, and some Fusarium spp. such as F. oxysporum include nonpathogenic strains. Despite the importance of rapid pathogen detection for disease control, identification of formae speciales within $F$. oxysporum often requires a troublesome and timeconsuming test.

\section{Corresponding author: H. Suga, E-mail: suga@gifu-u.ac.jp}

* The $\boldsymbol{e}$-Xtra logo stands for "electronic extra" and indicates that a supplementary table is included in the online edition.

Accepted for publication 12 November 2012.

http://dx.doi.org/10.1094/PDIS-07-12-0663-RE

(C) 2013 The American Phytopathological Society
Molecular markers to identify formae speciales or races of $F$. oxysporum would accelerate pathogen identification. Although host-determining factors are ideal markers, none have been identified for $F$. oxysporum except for the secreted in xylem (SIX) gene of $F$. oxysporum f. sp. lycopersici. Forma-specialis- or race-specific markers have been developed by using random amplified polymorphic DNA (RAPD) analyses followed by sequencing to design primers for sequence-characterized amplified regions or transposable elements (12).

Many types of transposable elements have been identified in $F$. oxysporum, and approximately $5 \%$ of the $F$. oxysporum genome appears to be composed of transposable elements (4). Whole-genome sequencing of $F$. oxysporum $\mathrm{f}$. sp. lycopersici revealed that about $28 \%$ of the entire genome was composed of repetitive sequences, and many types of transposable elements were detected. Five distinct superfamilies have been characterized: Tc1-mariner with the Pogo and the Impala families, $h A T$ with 13 distinct families, Mutator-like with 5 families, miniature inverted repeat transposable elements (MITEs) with 6 distinct families, and a Helitron-like family (13).

Molecular markers specific for F. oxysporum f. spp. albedinis (6) and chrysanthemi (18) were developed with a transposable element, Fot1. Another transposable element, Impala, was used to develop a molecular marker for $F$. oxysporum f. sp. dianthi race 4 (3). The inter-retrotransposon amplified polymorphism (IRAP) technique was used to develop molecular markers for $F$. oxysporum f. sp. lactucae race 1 (19).

In this study, our objectives were to (i) characterize transposable elements in F. oxysporum f. sp. fragariae and (ii) develop diagnostic polymerase chain reaction (PCR) primers for pathogen-specific elements to be used in pathogen detection. Developed primers were validated using pathogenic and nonpathogenic Fusarium strains obtained from the area in Japan where strawberry plants are cultivated and were used to detect artificially infested conidia of $F$. oxysporum f. sp. fragariae in soil.

\section{Materials and Methods}

Fungal strains. In total, 44 strains of $F$. oxysporum (Table 1) were used for PCR detection of transposable elements; these strains included 33 strains of $F$. oxysporum f. sp. fragariae from 
geographically dispersed prefectures in Japan, 1 strain each of five other formae speciales, and 6 strains that were isolated from strawberry root but did not show pathogenicity to strawberry (i.e., nonpathogenic strains). $F$. fujikuroi and $F$. raminearum s. str. were also used to confirm the specificity of diagnostic PCR for $F$. oxysporum $\mathrm{f}$. sp. fragariae. In all, 157 Fusarium strains isolated from the area where strawberry plants are cultivated in Nara prefecture, Japan in 2008 and 2009 (Supplementary Table S1) with FoG2 medium (17) were used for validation of diagnostic PCR developed in this study. Strains were maintained on potato dextrose agar (PDA) and kept at $6^{\circ} \mathrm{C}$ for short-term storage and at $-80^{\circ} \mathrm{C}$ in $50 \%$ glycerol for longterm storage.

Genomic DNA extraction. Each strain was cultured in potato dextrose broth (PDB) for 3 to 4 days. The resulting mycelial mat (2 to $3 \mathrm{~cm}$ in diameter) was air dried and, thereafter, ground to a powder by vortexing with small pieces of stainless steel wire in a microtube (22); then, DNA was extracted using a MagExtractorPlant-
Genome kit according to the manufacturer's instructions (Toyobo). The final DNA pellet was dissolved in $100 \mu \mathrm{l}$ of water and kept at $-30^{\circ} \mathrm{C}$ until used.

PCR detection of transposable elements. Selected regions of transposable elements were amplified by PCR with the primer sets shown in Table 2. Forward $(F)$ and reverse $(\mathrm{R})$ primers were designed from sequences of Foxy, Impala, and Hornetlin GenBank, and primers used in amplification of the other elements were obtained from previously published sequences (Table 2). Complementary sequences of Gagi and Gaga primers (19) were used as SkippyF and $-\mathrm{R}$, respectively. Amplification reactions were carried out in a $10-\mu$ reaction mixture that consisted of $1 \times$ PCR buffer (Applied Biosystems), $200 \mu \mathrm{M}$ dNTPs, $1 \mu \mathrm{M}$ each primer, 0.025 units of Taq DNA polymerase (Applied Biosystems), and $1 \mu \mathrm{l}$ of genomic DNA. PCR was performed in an iCycler thermal cycler (Bio-Rad Laboratories), using the following cycling parameters: $94^{\circ} \mathrm{C}$ for $2 \mathrm{~min}$ and 25 cycles of $94^{\circ} \mathrm{C}$ for $1 \mathrm{~min}, 63^{\circ} \mathrm{C}\left(54^{\circ} \mathrm{C}\right.$ only

Table 1. Strains used in this study

Primer pair ${ }^{\mathrm{a}}$

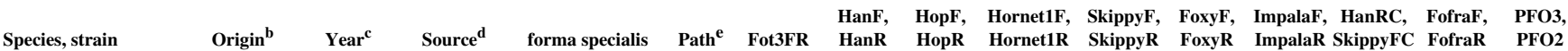

\begin{tabular}{|c|c|c|c|c|c|c|c|c|c|c|c|c|c|c|c|}
\hline \multicolumn{16}{|c|}{ Fusarium oxysporum } \\
\hline MAFF305557 & Unknown & 1978 & Strawberry & fragariae & + & + & + & + & + & + & + & + & + & + & + \\
\hline MAFF305558 & Unknown & 1978 & Strawberry & fragariae & + & + & + & + & + & + & + & + & + & + & + \\
\hline MAFF727510 & Nara & Unknown & Strawberry & fragariae & + & + & + & + & + & + & + & + & + & + & + \\
\hline MAFF744009 & Fukuoka & Unknown & Strawberry & fragariae & + & + & + & + & + & + & + & + & + & + & + \\
\hline FOF1 & Tochigi & 2000 & Strawberry & fragariae & + & + & + & + & + & + & + & + & + & + & + \\
\hline FOF10 & Tochigi & 2000 & Strawberry & fragariae & + & + & + & + & + & + & + & + & + & + & + \\
\hline FOF11 & Tochigi & 2000 & Strawberry & fragariae & + & + & + & + & + & + & + & + & + & + & + \\
\hline FOF12 & Tochigi & 2000 & Strawberry & fragariae & + & + & + & + & + & + & - & - & + & + & + \\
\hline FOF30 & Tochigi & 2000 & Strawberry & fragariae & + & + & + & + & + & + & + & + & + & + & + \\
\hline FOF50 & Tochigi & 2000 & Strawberry & fragariae & + & + & + & + & + & + & + & + & + & + & + \\
\hline FOF68 & Tochigi & 2000 & Strawberry & fragariae & + & + & + & + & + & + & + & + & + & + & + \\
\hline FOF84 & Tochigi & 2000 & Strawberry & fragariae & + & + & + & + & + & + & + & + & + & + & + \\
\hline FOF85 & Tochigi & 2000 & Strawberry & fragariae & + & + & + & + & + & + & + & + & + & + & + \\
\hline FOF87 & Tochigi & 2000 & Strawberry & fragariae & + & + & + & + & + & + & + & + & + & + & + \\
\hline FOF97 & Tochigi & 2000 & Strawberry & fragariae & + & + & + & + & + & + & + & + & + & + & + \\
\hline FOF98 & Tochigi & 2000 & Strawberry & fragariae & + & + & + & + & + & + & + & + & + & + & + \\
\hline FOF100 & Tochigi & 2000 & Strawberry & fragariae & + & + & + & + & + & + & + & + & + & + & + \\
\hline FOF103 & Tochigi & 2000 & Strawberry & fragariae & + & + & + & + & + & + & + & - & + & + & + \\
\hline FOF104 & Tochigi & 2000 & Strawberry & fragariae & + & + & + & + & + & + & + & + & + & + & + \\
\hline FOF120 & Tochigi & 2000 & Strawberry & fragariae & + & + & + & + & + & + & + & + & + & + & + \\
\hline FOF123 & Tochigi & 2000 & Strawberry & fragariae & + & + & + & + & + & + & + & + & + & + & + \\
\hline FOF126 & Tochigi & 2000 & Strawberry & fragariae & + & + & + & + & + & + & + & + & + & + & + \\
\hline FOF127 & Tochigi & 2000 & Strawberry & fragariae & + & + & + & + & + & + & + & + & + & + & + \\
\hline KMK & Tochigi & 2006 & Strawberry & fragariae & + & + & + & + & + & + & + & + & + & + & + \\
\hline UKA1 & Tochigi & 2009 & Strawberry & fragariae & + & + & + & + & + & + & + & + & + & + & + \\
\hline UKA2 & Tochigi & 2009 & Strawberry & fragariae & + & + & + & + & + & + & + & + & + & + & + \\
\hline UKA3 & Tochigi & 2009 & Strawberry & fragariae & + & + & + & + & + & + & + & - & + & + & + \\
\hline NRF0501 & Nara & 2005 & Strawberry & fragariae & + & + & + & + & + & + & + & + & + & + & + \\
\hline NRF0508 & Nara & 2005 & Strawberry & fragariae & + & + & + & + & + & + & + & + & + & + & + \\
\hline NRF0604 & Nara & 2006 & Strawberry & fragariae & + & + & + & + & + & + & + & + & + & + & + \\
\hline NRF0801 & Nara & 2008 & Strawberry & fragariae & + & + & + & + & + & + & + & + & + & + & + \\
\hline NRF0804 & Nara & 2008 & Strawberry & fragariae & + & + & + & + & + & + & + & + & + & + & + \\
\hline NRF0820 & Nara & 2008 & Strawberry & fragariae & + & + & + & + & + & + & + & + & + & + & + \\
\hline MAFF727519 & Shizuoka & 1984 & Strawberry & Nonpathogenic & - & - & + & + & + & + & + & + & - & - & + \\
\hline FOF13 & Tochigi & 2000 & Strawberry & Nonpathogenic & - & - & + & + & - & + & - & + & - & - & + \\
\hline FOF25 & Tochigi & 2000 & Strawberry & Nonpathogenic & - & - & + & + & - & + & - & - & - & - & + \\
\hline FOF55 & Tochigi & 2000 & Strawberry & Nonpathogenic & - & + & + & - & + & + & - & + & - & - & + \\
\hline FOF113 & Tochigi & 2000 & Strawberry & Nonpathogenic & - & - & + & - & - & + & - & + & - & - & + \\
\hline FOF121 & Tochigi & 2000 & Strawberry & Nonpathogenic & - & - & + & + & - & - & - & - & - & - & + \\
\hline GUS77 & Unknown & Unknown & Unknown & cucumerinum & NT & - & + & - & + & + & + & + & - & - & + \\
\hline GUS80 & Unknown & Unknown & Unknown & laganariae & NT & + & + & + & + & + & + & + & - & - & + \\
\hline GUS76 & Unknown & Unknown & Unknown & melonis & NT & + & + & + & + & + & + & + & - & - & + \\
\hline GUS126 & Gifu & Unknown & Tomato & radicis lycopersici & NT & + & + & + & + & + & + & + & - & - & + \\
\hline GUS78 & Unknown & Unknown & Unknown & spinaciae & NT & + & + & + & + & + & + & + & - & - & + \\
\hline \multicolumn{16}{|l|}{ F. fujikuroi } \\
\hline NRF0812 & Nara & 2008 & Strawberry & $\cdots$ & NT & NT & NT & NT & NT & NT & NT & NT & NT & - & - \\
\hline \multicolumn{16}{|c|}{ F. graminearum s. str. } \\
\hline 0407011 & Fukushima & 2004 & Wheat & $\ldots$ & NT & NT & NT & NT & NT & NT & NT & NT & NT & - & - \\
\hline
\end{tabular}

${ }^{\text {a }}$ Presence (+) or absence (-) of PCR product with the size of amplified length indicated in Table 2. NT $=$ not tested.

b Geographic origin (prefecture of Japan)

c Year of isolation.

d Isolation source.

${ }^{\mathrm{e}}$ Result of pathogenicity test in this study. 
for Hop) for $1 \mathrm{~min}$, and $72^{\circ} \mathrm{C}$ for $1 \mathrm{~min}$. PCR products were detected by electrophoresis in a $1.0 \%$ agarose gel in Tris-borateEDTA buffer. Band size was estimated by comparison to a 100-bp ladder marker (New England Biolabs). The DNA bands were visualized under UV light after staining the gel in ethidium bromide at $0.5 \mu \mathrm{g} / \mathrm{ml}$.

Sequencing of transposable elements. PCR products of the expected size for each transposable element from strain FOF10 were sequenced with the same primers that were used for PCR (Table 2). Gels containing the expected size of PCR products after electrophoresis with $1 \%$ SeaKem GTG Agarose (Takara Bio Inc.) were used for purification by the Nucleospin Gel and PCR Clean Up kit (Takara Bio Inc.). At first, purified PCR products (except for Fot3) were directly sequenced by BigDye terminator V3.1 cycle sequencing kits (Applied Biosystems) and then run on an ABI 3100 genetic analyzer (Applied Biosystems). Foxy, Han, and Hornet1 showed clear electropherogram traces whereas Hop, Impala, and Skippy showed mixed signals (multiple peaks) at some portions of the trace. In order to obtain clear signals, these PCR products were cloned into a plasmid, pCR4-TOPO (Life Technologies Inc.). Plasmids were extracted with an ABI PRISM Miniprep Kit (Life Technologies Inc.) according to the manufacturer's instructions. For each transposable element, 7 to 12 colonies in which insert DNA was confirmed were selected for further screening by restriction enzyme digestion. Insert DNA was amplified by PCR with primer pairs corresponding to each transposable element (Table 2) and then digested by individual restriction enzymes: AluI, HhaI, HinfI, MseI, RsaI, and Sau3AI. Fragment patterns were compared among colonies of each transposable element with $2.5 \%$ agarose gel electrophoresis. Plasmids with different patterns were used for sequencing with M13M4 (5'-GTTTTCCCAGTCACGACGTTG TAAA- $\left.3^{\prime}\right)$ and M13RV (5'-CAGGAAACAGCTATGACCATG ATTA-3') primers. The PCR product of Fot 3 was also cloned into the pCR4-TOPO vector (Life Technologies) and sequenced with M13M4, M13RV and HS475 primers (5'-CAGTTTCCAGTCACT CTCCA-3') because the PCR product has the same primer sequence at both ends. Nucleotide sequences were edited and aligned using Sequencher (version 3.1.1; Gene Codes) and Genetyx (version 4.0; Genetyx). Sequences have been deposited in GenBank (Table 2).

IRAP-PCR. Complementary sequence primers (FC or RC) for Fot3, Han, Hop, Hornet1, and Skippy were used for IRAP-PCR
(Table 2). In total, 23 primer combinations out of 60 possible combinations were examined using $F$. oxysporum $\mathrm{f}$. sp. fragariae strain FOF10, five other formae speciales (strains GUS76, -77 -78, -80, and -126), and a nonpathogenic $F$. oxysporum strain FOF13. Five combinations assumed the presence of the same type of transposable element in the same direction: Fot3FRC only, HanFC and RC, HopFC and RC, Hornet1FC and RC, and SkippyFC and RC. Eight combinations assumed the presence of the same type of transposable element in the inverse direction: HanFC only, HanRC only, HopFC only, HopRC only, Hornet1FC only, Hornet1RC only, SkippyFC only, and SkippyRC only. Ten combinations assumed the presence of different types of transposable elements in the same or the inverse direction: Fot3FRC and HopFC, Fot3FRC and HopRC, HanFC and SkippyFC, HanFC and SkippyRC, HanRC and SkippyFC, HanRC and SkippyRC, Hornet1FC and HopFC, Hornet1FC and HopRC, Hornet1RC and HopFC, and Hornet1RC and HopRC. The reaction mixture was the same used for transposable elements PCR. PCR was performed by the following cycling parameters: $94^{\circ} \mathrm{C}$ for $2 \mathrm{~min}$ and 30 cycles of $94^{\circ} \mathrm{C}$ for $1 \mathrm{~min}$, $60^{\circ} \mathrm{C}$ for $1 \mathrm{~min}$, and $72^{\circ} \mathrm{C}$ for $3 \mathrm{~min}$. PCR products were detected by $1.0 \%$ agarose gel electrophoresis.

Designing $F$. oxysporum f. sp. fragariae-specific primers and multiplex PCR with $\boldsymbol{F}$. oxysporum-specific primers. The 268 -bp DNA detected from $F$. oxysporum $\mathrm{f}$. sp. fragariae strain FOF10 by IRAP-PCR with HanRC and SkippyFC primers was sequenced with the same primers (Fig. 1). FofraF and FofraR primers (renamed from HS430 and HS432 primers by Suga et al. [21]) were newly designed from the revealed sequence to avoid extra DNA amplifications (Fig. 1; Table 2).

Optimum conditions for multiplex PCR with FofraF and FofraR primers and $F$. oxysporum-specific primers (PFO2 and PFO3) (5) were established using $F$. oxysporum $\mathrm{f}$. sp. fragariae strain FOF10, five other formae speciales (strains GUS76, -77 -78, -80, and -126), nonpathogenic F. oxysporum strain FOF13, F. fujikuroi, and F. graminearum s. str. (Table 1 ). Annealing temperatures and primer concentrations were optimized, and final amplification reaction conditions were determined in a $10-\mu$ reaction mixture that consisted of $1 \times$ GoTaq buffer (Promega Corp.), $200 \mu \mathrm{M}$ dNTPs, 2 $\mu \mathrm{M}$ each FofraF and FofraR primers (Table 2), $1 \mu \mathrm{M}$ each PFO2 and PFO3 primers (5), 2.5 units of Go Taq polymerase (Promega Corp.), and $2 \mu \mathrm{l}$ of genomic DNA. PCR was performed using the

Table 2. Primers used in this study

\begin{tabular}{|c|c|c|c|c|c|c|}
\hline \multicolumn{4}{|c|}{ Primer sequence $\left(5^{\prime}-3^{\prime}\right)^{\mathrm{a}}$} & \multirow[b]{2}{*}{ Target sequence } & \multicolumn{2}{|c|}{ Length (bp) } \\
\hline & Forward & & Reverse & & Expected $^{\mathrm{b}}$ & Amplified $^{\mathrm{c}}$ \\
\hline Fot3FR & $\begin{array}{l}\text { CCGGCAAGCAAAAAAAAAGTTTC } \\
\text { (Fot3, Hua-Van et al. [8]) }\end{array}$ & & Fot3FR was used as reverse primer & Fot3 & 2,117 (AF076631) & 2,133 (JX204293) \\
\hline Fot3FRC & GAAACTTTTTTTTTGCTTGCCGG & & & Between Fot3 & & \\
\hline HanF & $\begin{array}{l}\text { TGAATGTTGGAGGGTTCACC } \\
\text { (S1, Hua-Van et al. [8]) }\end{array}$ & HanR & $\begin{array}{l}\text { CAGATATTGAGGTGAATCGTG } \\
\text { (S2, Hua-Van et al. [8]) }\end{array}$ & Han & $200(\mathrm{AF} 076629)$ & $200($ JX204294) \\
\hline HanFC & $\begin{array}{l}\text { GAACCCTCCAACATTCAACA } \\
\text { (Hani, Pasquali et al. [19]) }\end{array}$ & HanRC & $\begin{array}{l}\text { CACGATTCACCTTAATATCTGACA } \\
\text { (Hana, Pasquali et al. [19]) }\end{array}$ & Between Han & & \\
\hline HopF & AAGAGGCATAGGTGGCCTTAT & HopR & TTACACAGGCTTTCCTTTGC & Hop & 394 (AY267761) & $\begin{array}{l}394 \text { (JX204295), } \\
412(\text { JX204296) }\end{array}$ \\
\hline HopFC & ATAAGGCCACCTATGCCTCTT & HopRC & TTATTCGCACGACCGGTGGTG & Between Hop & & \\
\hline Hornet1F & TGTGGATCCATATCCATTCCA & Hornet1R & TGATCGTTGACGATCGAGAA & Hornet1 & 792 (AF076626) & 798 (JX204297) \\
\hline Hornet1FC & TGGAATGGATATGGATCCACA & Hornet1RC & TTCTCGATCGTCAACGATCA & Between Hornet1 & & \\
\hline SkippyF & TGTTACGACCCTAGCGGTTA & SkippyR & TGTGACGGTTGGTTCCC & Skippy & 429 (L34658) & $\begin{array}{l}396 \text { (JX204298, } \\
\text { JX204299, JX204300) }\end{array}$ \\
\hline SkippyFC & $\begin{array}{l}\text { TAACCGCTAGGGTCGTAACA } \\
\text { (Gagi, Pasquali et al. [19]) }\end{array}$ & SkippyRC & $\begin{array}{l}\text { GGGAACCAACCGTCACA } \\
\text { (Gaga, Pasquali et al. [19]) }\end{array}$ & Between Skippy & & \\
\hline FoxyF & CTGGGTGGCTGTAACGAAG & FoxyR & GGAATTTTGGAGAGTTCGCCT & Foxy & 483 (AJ250814) & 460 (JX204301) \\
\hline ImpalaF & GCCTCRAAAGCTYAYAGAAGA & ImpalaR & TAGATGCCKMTGGCRTTGA & Impala & $\begin{array}{l}459 \text { (AF282722, } \\
\text { AF363434, AF363409) }\end{array}$ & $\begin{array}{l}459 \text { (JX204302) } \\
464 \text { (JX204303) }\end{array}$ \\
\hline SkippyFC & Described above & HanRC & Described above & Between Han and Skippy & & 268 (JX204304) \\
\hline FofraF & CAGACTGGGGTGCTTAAAGTT & FofraR & AACCGCTAGGGTCGTAACAAA & Between Han and Skippy & & 239 \\
\hline $\mathrm{PFO} 3$ & $\begin{array}{l}\text { CGGGGGATAAAGGCGG } \\
\text { (Edel et al. [5]) }\end{array}$ & $\mathrm{PFO} 2$ & $\begin{array}{l}\text { CCCAGGGTATTACACGGT } \\
\text { (Edel et al. [5]) }\end{array}$ & $18 \mathrm{~S}$ rDNA & & 70 \\
\hline
\end{tabular}

${ }^{a}$ Primers previously published are shown with the reference in parentheses. Others were designed in this study.

${ }^{\mathrm{b}}$ Length was as expected based on the GenBank accession number as shown in parentheses.

${ }^{c}$ Length amplified from Fusarium oxysporum f. sp. fragariae strain FOF10. GenBank accession number is shown in parentheses. 
following cycling parameters: $94^{\circ} \mathrm{C}$ for 2 min and 30 cycles of $94^{\circ} \mathrm{C}$ for $1 \mathrm{~min}, 63^{\circ} \mathrm{C}$ for $1 \mathrm{~min}$, and $72^{\circ} \mathrm{C}$ for $1 \mathrm{~min}$. PCR products were detected by $2.5 \%$ agarose gel electrophoresis. Expected sizes of DNA fragments amplified by the FofraF and FofraR primer pair and PFO2 and PFO3 primer pair were 239 bp (Fig. 1) and $70 \mathrm{bp}$ of DNA (5), respectively. The sequence of the 239-bp DNA fragment amplified from $F$. oxysporum $\mathrm{f}$. sp. fragariae strain FOF10 was confirmed by sequencing with FofraF and FofraR primers (Table 2).

PCR detection of $\boldsymbol{F}$. oxysporum $\mathbf{f}$. sp. fragariae in soils. Brown lowland-type soils were artificially infested with conidia of $F$. oxysporum f. sp. fragariae strain FOF10. Conidia produced on synthetic low-nutrient agar medium were harvested with sterile water and adjusted at $1 \times 10^{6} / \mathrm{ml}$. This suspension was sequentially diluted to obtain $10^{5}, 10^{4}$, or $10^{3}$ conidia/ml and then $20 \mu \mathrm{l}$ of each or sterile water was mixed with $0.2 \mathrm{~g}$ of brown lowland-type soil (i.e., $0,10^{2}, 10^{3}, 10^{4}$, or $10^{5}$ conidia/g of soil). DNA was extracted from the soil containing conidia according to Kageyama et al. (9), with some modifications. For testing the effect of preculturing, 40 $\mu \mathrm{l}$ of FoG2 medium without agar (17) was added to the soil containing conidia and incubated for 4 days at $25^{\circ} \mathrm{C}$ before DNA extraction. RNase A was not used in this study, and the mixture was kept at $60^{\circ} \mathrm{C}$ for $15 \mathrm{~min}$ instead of at $50^{\circ} \mathrm{C}$ for $60 \mathrm{~min}$. After incubation, $150 \mu \mathrm{l}$ of $3 \mathrm{M} \mathrm{NaOAc}$ was added and the samples were kept on ice for $15 \mathrm{~min}$. The suspension was centrifuged at $18,000 \times$ $g$ for $10 \mathrm{~min}$, the upper layer $(300 \mu \mathrm{l})$ was transferred to a clean tube, and DNA was further purified with a MagExtractorPlantGenome kit (Toyobo). The upper layer of suspension was mixed with $600 \mu \mathrm{l}$ of absorbent and $40 \mu \mathrm{l}$ of magnetic bead suspensions. Then, purification steps were continued according to the manufacturer's instructions. Finally, DNA was eluted with $50 \mu \mathrm{l}$ of water and $1 \mu \mathrm{l}$ was used for PCR. PCR conditions were the same as the multiplex PCR, with the following modifications: only FofraF and FofraR primers were used, $0.4 \mathrm{mg}$ of bovine serum albumin was included in the reaction mixture, and the thermal cycling number was increased from 30 to 40 . The experiment from preparation of the soil containing conidia was repeated twice.

Pathogenicity test. Pathogenicity tests were performed in a greenhouse during July and August in Japan. Strains were cultured in $100 \mathrm{ml}$ of PDB at 25 to $28^{\circ} \mathrm{C}$ for 10 days. Conidial suspensions obtained by culture filtration with two layers of gauze were adjusted to approximately $1 \times 10^{5} / \mathrm{ml}$ with water, and $10 \mathrm{ml}$ was poured into a pot $(9 \mathrm{~cm}$ in diameter) in which nursery-grown strawberry (Fragariae $\times$ ananassa Duch. 'Asukarubi') plants were growing. The pots were returned to a greenhouse and foliar distortions, a typical symptom of Fusarium wilt, were observed 1 month after inoculation.

\section{Results}

Transposable elements in $\boldsymbol{F}$. oxysporum f. sp. fragariae. PCR was used to amplify the following transposable elements from $F$. oxysporum f. sp. fragariae: Fot3, Foxy, Han, Hop, Hornet1, Impala, and Skippy (Table 1). DNA fragments of the expected sizes for Fot3, Han, Hop, Hornet1, and Skippy were obtained for all 33 strains of $F$. oxysporum f. sp. fragariae tested, whereas those for Foxy were amplified in all but 1 strain and those for Impala were amplified in all but 3 strains of $F$. oxysporum f. sp. fragariae (Table 1).

The PCR products for each transposable element (except for Fot3 from strain FOF10) were directly sequenced. The sequences of Foxy, Han, and Hornet1 could be determined, whereas the sequences for Hop, Impala, and Skippy showed mixed signals (multiple peaks) at some portions of the trace. Therefore, PCR products were cloned into a plasmid vector, and the plasmids that showed different restriction enzyme patterns for each transposable element were sequenced. Two types of sequences were detected for Hop, two types for Impala, and three types for Skippy (Table 2). The PCR product of Fot 3 was also sequenced after cloning into a plasmid. A BLAST search showed that all of the PCR products amplified from strain FOF10 using transposable element primer pairs have the highest similarities to the corresponding transposable elements of $F$. oxysporum in GenBank.

The expected sizes of DNAs for each transposable element examined were amplified in some nonpathogenic stains and also in five formae speciales (Table 1). Therefore, $F$. oxysporum $f$. sp. fragariae could not be uniquely identified by these PCR primer pairs.

IRAP-PCR. In all, 23 primer combinations were examined using $F$. oxysporum f. sp. fragariae strain $\mathrm{FOF} 10$, each strain of five other formae speciales (strain GUS76, -77 -78, -80, and -126), and a nonpathogenic F. oxysporum strain FOF13. Fot3, Han, Hop, Hornet1, and Skippy were detected from all 33 strains of F. oxysporum f. sp. fragariae tested, and their complementary sequence primers (FC or RC) were used for IRAP-PCR. Nine primer combinations resulted in no amplification of these seven strains. Fourteen combinations amplified DNAs in at least one strain. The HanRC and SkippyFC combination amplified a 268-bp DNA fragment only in F. oxysporum f. sp. fragariae strain FOF10, although additional DNAs were also amplified from this strain and the other strains (Fig. 2). Specific amplification of the 268-bp DNA fragment was confirmed in all 33 strains of $F$. oxysporum f. sp. fragariae (Table $1)$.

Designing $F$. oxysporum f. sp. fragariae-specific primers and multiplex PCR with $F$. oxysporum-specific primers. FofraF and FofraR primers were designed to avoid unspecific DNA amplifica-

\title{
5'-cacgattcacactaatatctgacacCACCAGACTGGGGTGCTTAAAGTTTATTACCATCCA FofraF GGACCACCTAATGCATAACTAAAATTTCGCTCCTCCCATACAAAATCCAAAT
}

\author{
TTTGATGTCCACAAAAAGGCCCGATTCTCAATTAATAAATGAGACTTTGGA
}

\author{
GAAAGTTTCTAGAAAATTGCTCAAATTTTACTCTCTGCGTGGTTTTTTGACC
}

\section{TCCCGACCGCTGCGTGTGCGCTGGCAGTGCTTtgttacgaccetagcggtta-3' \\ FofraR}

Fig. 1. Positions of FofraF and FofraR primers in the Fusarium oxysporum f. sp. fragariae-specific 268-bp DNA amplified by polymerase chain reaction (PCR) with the HanRC and SkippyFC primers. Lowercase characters indicate the positions of the HanRC and SkippyFC primers. FofraF and FofraR primers amplify a 239-bp DNA fragment by PCR. 
tions in F. oxysporum f. sp. fragariae (Fig. 1), and conditions for multiplex PCR with $F$. oxysporum-specific primers (PFO2 and PFO3) (5) were standardized (Fig. 3). The expected sizes of DNAs, 239 bp for the FofraF and FofraR primer pair and 70 bp for the $\mathrm{PFO} 2$ and PFO3 primer pair, were amplified from all 33 strains of F. oxysporum f. sp. fragariae, whereas only a 70-bp DNA fragment was amplified in the five other formae speciales and the nonpathogenic $F$. oxysporum (Table 1).

Validation of developed multiplex PCR. The accuracy of diagnosis by the multiplex PCR was confirmed by testing 157 Fusarium strains from the area where strawberry plants are cultivated in Nara prefecture. The results of the multiplex PCR were compared with the results of a pathogenicity test. The multiplex PCR determined that 79 strains were $F$. oxysporum f. sp. fragariae based on amplification of both the 239- and 70-bp DNA fragments. Of the 79 strains, 73 showed typical disease symptoms on strawberry, whereas 6 strains did not show any symptoms on strawberry by the pathogenicity test. The pathogenicity test was repeated twice for these six strains but did not produce symptoms in the subsequent tests. The multiplex PCR determined that the remaining 58 strains were nonpathogenic $F$. oxysporum based on amplification of only the 70-bp DNA fragment, and 20 strains were some species other than $F$. oxysporum based on no amplification. None of these 58 strains produced symptoms on strawberry by the pathogenicity test.

PCR detection of $\boldsymbol{F}$. oxysporum f. sp. fragariae in soils. Conidia of $F$. oxysporum f. sp. fragariae were mixed in soils at $0,10^{2}$, $10^{3}, 10^{4}$, or $10^{5}$ conidia/g of soil, and DNA was extracted immediately or after preculturing in FoG2 medium (17). Positive amplifications were observed in samples where the conidia levels were $10^{3}, 10^{4}$, and $10^{5}$ conidia/g of soil without preculturing by PCR with the FofraF and FofraR primer pair (Fig. 4). When samples were precultured, positive amplifications were observed in samples where the conidia levels were $10^{2}, 10^{3}, 10^{4}$, and $10^{5}$ conidia/g (Fig. 4).

\section{Discussion}

In this study, several transposable elements (Fot3, Han, Hop, Hornet1, and Skippy) were detected in F. oxysporum f. sp. fragariae by PCR. At the least, several sequences of Hop, Impala, and Skippy are present in a single strain of $F$. oxysporum $\mathrm{f}$. sp. fragariae. Based on these PCR results, IRAP-PCR was performed and a PCR method was developed to identify $F$. oxysporum f. sp. fragariae.

Soilborne diseases of strawberry cause serious economic losses worldwide and rapid detection is important for optimal disease control. PCR primers have been developed for detection of Phytophthora rot pathogens Phytophthora nicotianae and P. cactorum (11) and Verticillium wilt pathogen Verticillium dahliae (2) but not for the Fusarium wilt pathogen. In the case of Phytophthora rot and

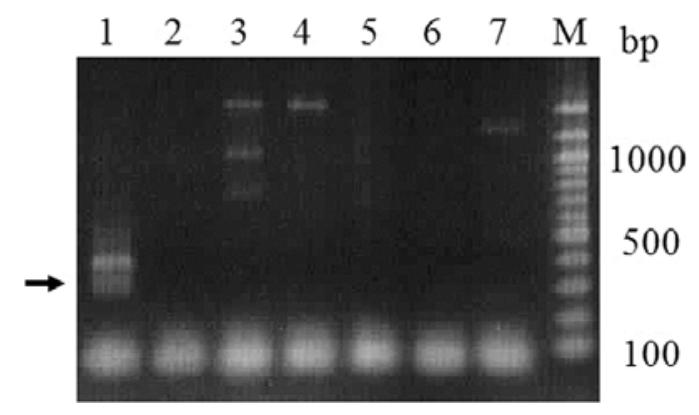

Fig. 2. Inter-retrotransposon amplified polymorphism polymerase chain reaction (PCR) with the HanRC and SkippyFC primers. PCR products separated by electrophoresis in a $1.0 \%$ agarose gel. Lane 1, Fusarium oxysporum f. sp. fragariae strain FOF10; lane 2, nonpathogenic F. oxysporum strain FOF13; F. oxysporum f. spp. lane 3, melonis; lane 4, cucumerinum; lane 5, spinaciae; lane 6, laganariae; lane 7 , radicis lycopersici; lane M, 100-bp ladder. An arrow indicates F. oxysporum f. sp. fragariae-specific 268-bp DNA fragment.
Verticillium wilt, PCR primers that can identify the fungus at species level are sufficient for pathogen identification. However, such primers are inadequate for identification of the Fusarium wilt pathogen because saprobic $F$. oxysporum is ubiquitous and only $F$. oxysporum f. sp. fragariae causes Fusarium wilt on strawberry. PCR primers that can discriminate $F$. oxysporum f. sp. fragariae from nonpathogenic $F$. oxysporum are required for pathogen identification.

Diagnostic PCR rather than pathogenicity testing is more effective for the quick determination of pathogenic strains. PCR primers to discriminate forma specialis or race of $F$. oxysporum have been designed using RAPD analyses and transposable elements (12). Recently, Southwood et al. (20) developed diagnostic primers for two vegetative compatibility groups of $F$. oxysporum f. sp. cepae by IRAP-PCR. In this study, HanRC and SkippyFC primers amplified a 268-bp DNA fragment from $F$. oxysporum $\mathrm{f}$. sp. fragariae by IRAP-PCR (Fig. 2). A BLAST search indicated that the nucleotide sequence of approximately $200 \mathrm{bp}$ of amplified DNA at the SkippyFC site was similar to the IRAP-Two sequence obtained from $F$. oxysporum f. sp. cepae (20). Similar sequences were also found in the genomic sequences of $F$. oxysporum f. sp. melonis and $F$. oxysporum II5 (Fusarium comparative sequencing project, Broad Institute of Harvard and MIT; http://www.broadinstitute.org/). When the remaining 43-bp sequence without the HanRC primer sequence was used for the BLAST search, the longest match was $29 \mathrm{bp}$ in the $F$. oxysporum PHW808 genome sequence (Fusarium comparative sequencing project, Broad Institute of Harvard and MIT; http://www.broadinstitute.org/). Similar sequences of 23 and a $27 \mathrm{bp}$ were also detected in the genome of $F$. oxysporum $\mathrm{f}$. $\mathrm{sp}$. melonis. Consequently, $F$. oxysporum f. sp. melonis has sequences similar to both to approximately $200 \mathrm{bp}$ and the remaining $43 \mathrm{bp}$ of the target sequence for $F$. oxysporum f. sp. fragariae diagnostic PCR. However, the supercontigs were different for the similar sequences. In addition, no PCR product was detected with the FofraF and FofraR primer pair in F. oxysporum f. sp. melonis (Table 1).

Transposable elements are enriched in the virulence chromosomes in tomato wilt pathogen $F$. oxysporum f. sp. lycopersici $(13,24)$ and the pathogenicity cluster of the pea root rot pathogen Fusarium solani f. sp. pisi $(7,23)$. Compared with nonpathogenic strains, this study revealed that all six formae speciales, including F. oxysporum f. sp. fragariae, have many types of transposable elements. Because more than 100 formae speciales are known in $F$. oxysporum, primers used for IRAP-PCR in this study may be useful to develop a molecular marker for identification and detection of other forma specialis and also to investigate the virulence region of the F. oxysporum genome.

Transposable elements are grouped into two classes: class I elements mobilize via an RNA intermediate and class II elements via a DNA cut-and-paste mechanism. IRAP-PCR targets the region

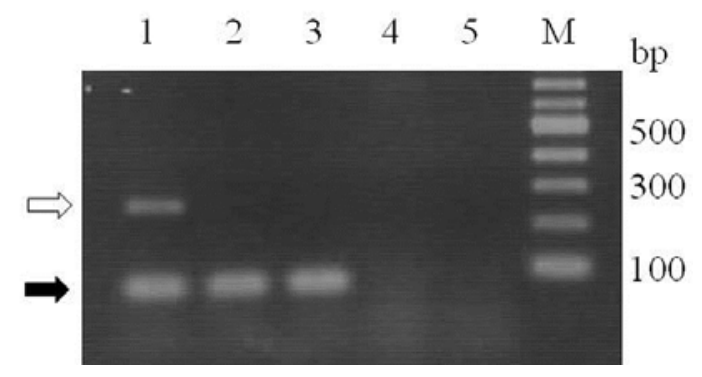

Fig. 3. Multiplex polymerase chain reaction (PCR) with Fusarium oxysporum f. sp. fragariae-specific primers and $F$. oxysporum-specific primers. PCR products separated by electrophoresis in a $2.5 \%$ agarose gel. Lane $1, F$. oxysporum f. $s p$ fragariae strain FOF10; lane 2, F. oxysporum f. sp. radicis lycopersici; lane 3, nonpathogenic $F$. oxysporum strain FOF13; lane 4, F. fujikuroi; lane 5, $F$. graminearum s. str.; lane M, 100-bp ladder. White and black arrows indicate an $F$. oxysporum f. sp. fragariae-specific DNA fragment and an F. oxysporum-specific DNA fragment, respectively. 
A

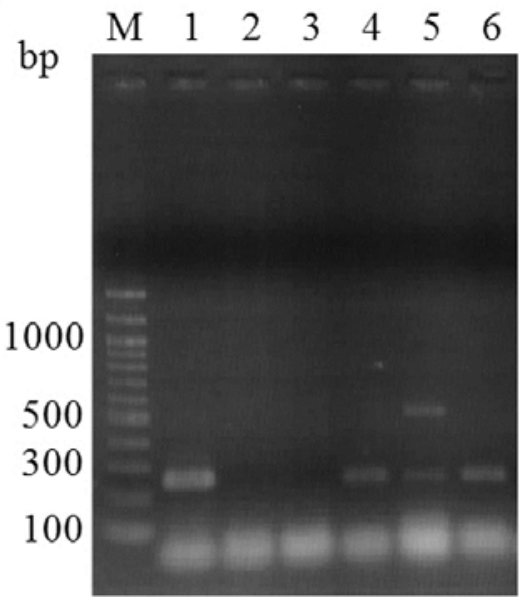

B

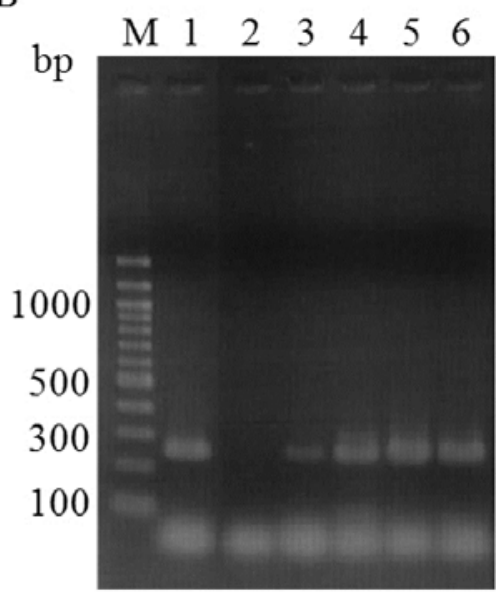

Fig. 4. A, Polymerase chain reaction (PCR) detection of Fusarium oxysporum f. sp. fragariae in soils without preculturing. PCR products with the FofraF and FofraR primers separated by electrophoresis in a 1.5\% agarose gel. Lane M, 100-bp ladder; lane 1, F. oxysporum f. sp. fragariae strain FOF10 genomic DNA and lanes 2-6, conidia of the strain FOF10 were mixed in soils at rates of $0,10^{2}, 10^{3}, 10^{4}$, or $10^{5}$ conidia/g of soil, respectively. B, PCR detection of Fusarium oxysporum f. sp. fragariae in soils after preculturing. Same as A, except DNA was extracted after preculturing in FoG2 medium for 4 days at $25^{\circ} \mathrm{C}$.

between the long terminal repeat of class I transposable elements. This region is not influenced by transposition events as can be the case with active class II transposable elements and, therefore, is more suitable for use as a molecular marker. The FofraR primer is very similar to the SkippyFC primer (Gagi primer in Pasquali et al. [19]), whereas the FofraF primer was designed from an internal region between HanRC and SkippyFC. Consequently, the PCR specificity with these primers should be stable because no false negatives were detected by the diagnostic PCR in this study. However, six strains determined as $F$. oxysporum $\mathrm{f}$. sp. fragariae by diagnostic PCR with FofraF and FofraR primers did not produce symptoms on strawberry by the pathogenicity test. The results of both diagnostic PCR and pathogenicity tests were repeatedly confirmed. There are two possibilities for this incongruence. One possibility is attributed to the aggressiveness of the strains. The aggressiveness in $F$. oxysporum f. sp. fragariae varies among strains, and low aggressiveness may not be detected by the pathogenicity test using only one strawberry cultivar, Asukarubi, in this study. Otherwise, degeneration during culturing on media may have contributed to the lost in pathogenicity of these strains. Another possibility is that diagnostic PCR may have generated a false positive. The stability of the diagnostic PCR could also be associated with the genetic variation of $F$. oxysporum f. sp. fragariae. Fusarium wilt of strawberry has occurred worldwide recently and RAPD analyses showed a high level of genetic variation in Korea $(15,16)$. However, genetic variation of this pathogen has not been well investigated to date. Therefore, further studies will be needed to analyze the accuracy of the diagnostic PCR developed in this study using field isolates with more varied geographic origins.

Selective media have been used to isolate $F$. oxysporum, and a time-consuming pathogenicity test is required to determine the identity of pathogens after isolation. The diagnostic PCR developed in this study is beneficial for control of Fusarium wilt of strawberry because it can quickly determine the identity of the pathogen and can handle many samples simultaneously. This technique may also be useful for the direct detection of $F$. oxysporum f. sp. fragariae from field soil, though PCR detection was demonstrated by using artificially prepared soil. PCR amplification was successfully observed with brown lowland-type soil containing more than $10^{3}$ conidia of $F$. oxysporum $\mathrm{f}$. sp. fragariae per gram of soil. Generally, the sensitivity of PCR detection of pathogens from soil is influenced by many factors, especially the purity of extracted DNA (9). Preculturing might increase the sensitivity of PCR detection because a 10 -fold increase was observed in this study, although the effect may be limited depending on soil types or pathogen source. Not only the presence of pathogens but also the concentration of pathogens is important for control of soilborne pathogens. Our future studies will be focused on the quantitative detection of $F$. oxysporum $\mathrm{f}$. sp. fragariae from soil using the PCR methods developed in this study.

\section{Acknowledgments}

This work was supported, in part, by the strawberry project of Japan ("Development of diagnostic program for production of pathogen-free seedlings of strawberry", research and development projects for application in promoting new policy of Agriculture Forestry and Fisheries). We thank M. Seo, T. Scott, and M. Funasaka (Gifu University, Japan), for technical support.

\section{Literature Cited}

1. Arroyo, F. T., Llergo, Y., Aguado, A., and Romero, F. 2009. First report of Fusarium Wilt caused by Fusarium oxysporum on strawberry in Spain. Plant Dis. 93:323-323.

2. Bilodeau, G. J., Koike, S. T., Uribe, P., and Martin, F. N. 2012. Development of an assay for rapid detection and quantification of Verticillium dahliae in soil. Phytopathology 102:331-343.

3. Chiocchetti, A., Bernardo, I., Daboussi, M.-J., Garibaldi, A., Gullino, M. L., Langin T., and Migheli, Q. 1999. Detection of Fusarium oxysporum f. sp. dianthi in carnation tissue by PCR amplification of transposon insertions. Phytopathology 89:1169-1175.

4. Daboussi, M. J., and Langin, T. 1994. Transporsable element in the fungal plant pathogen Fusarium oxysporum. Genetica 93:49-59.

5. Edel, V., Steinberg, C., Gautheron, N., and Alabouvette, C. 2000. Ribosomal DNA-targeted oligonucleotide probe and PCR assay specific for Fusarium oxysporum. Mycol. Res. 104:518-526.

6. Fernandez, D., Ouinten, M., Tantaoui, A., Geiger, J. P., Daboussi, M. J., and Langin, T. 1998. Fot 1 insertions in the Fusarium oxysporum f. sp. albedinis genome provide diagnostic PCR targets for detection of the date palm pathogen. Appl. Environ. Microbiol. 64:633-636.

7. Han, Y., Liu, X., Benny, U., Kistler, H. C., and VanEtten, H. D. 2001. Genes determining pathogenicity to pea are clustered on a supernumerary chromosome in the fungal plant pathogen. Nectria haematococca. Plant J. 25:305314.

8. Hua-Van, A., Daviére, J.-M., Kaper, F., Langin, T., and Daboussi, M.-J. 2000. Genome organization in Fusarium oxysporum: clusters of class II transposons. Curr. Genet. 37:339-347.

9. Kageyama, K., Komatsu, T., and Suga, H. 2003. Refined PCR protocol for detection of plant pathogens in soil. J. Gen. Plant Pathol. 69:153-160.

10. Koike, S. T., Kirkpatrick, S. C., and Gordon, T. R. 2009. Fusarium wilt of strawberry caused by Fusarium oxysporum in California. Plant Dis. 93:1077-1077.

11. Li, M., Asano, T., Suga, H., and Kageyama, K. 2011. A multiplex PCR for the detection of Phytophthora nicotianae and P. cactorum, and a survey of their occurrence in strawberry production areas of Japan. Plant Dis. 95:1270-1278.

12. Lievens, B., Rep, M., and Thomma, B. P. H. J. 2008. Recent developments in the molecular discrimination of formae speciales of Fusarium oxysporum. Pest Manage. Sci. 64:781-788.

13. Ma, L. J., van der Does, H. C., Borkovich, K. A., Coleman, J. J., Daboussi, M. J., Di Pietro, A., Dufresne, M., Freitag, M., Grabherr, M., Henrissat, B., Houterman, P. M., Kang, S., Shim, W. B., Woloshuk, C., Xie, X., Xu, J. R., Antoniw, J., Baker, S. E., Bluhm, B. H., Breakspear, A., Brown, D. W., Butchko, R. A. E., Chapman, S., Coulson, R., Coutinho, P. M., Danchin, E. 
G. J., Diener, A., Gale, L. R., Gardiner, D. M., Goff, S., Hammond-Kosack, K. E., Hilburn, K., Hua-Van, A., Jonkers, W., Kazan, K., Kodira, C. D., Koehrsen, M., Kumar, L., Lee, Y. H., Li, L., Manners, J. M., Miranda-Saavedra, D., Mukherjee, M., Park, G., Park, J., Park, S. Y., Proctor, R. H., Regev, A., Ruiz-Roldan, M. C., Sain, D., Sakthikumar, S., Sykes, S., Schwartz, D. C., Turgeon, B.G., Wapinski, I., Yoder, O., Young, S., Zeng, Q., Zhou, S., Galagan, J., Cuomo, C. A., Kistler, H. C., and Rep, M. 2010. Comparative genomics reveals mobile pathogenicity chromosomes in Fusarium. Nature 464:367-373.

14. Matsuo, T. 1972. Taxonomic studies on phytopathogenic Fusaria. Ann. Phytopathol. Soc. Jpn. 38:167-169.

15. Nagarajan, G., Kang, S. W., Nam, M. H., Song, J. Y., Yoo, S. J., and Kim, H. G. 2006. Characterization of Fusarium oxysporum f. sp. fragariae based on vegetative compatibility group, random amplified polymorphic DNA and pathogenicity. Plant Pathol. J. 22:222-229.

16. Nagarajan, G., Nam, M. H., Song, J. Y., Yoo, S. J., and Kim, H. G. 2004. Genetic variation in Fusarium oxysporum $\mathrm{f}$. sp. fragariae populations based on RAPD and rDNA RFLP analyses. Plant Pathol. J. 20:264-270.

17. Nishimura, N. 2007. Selective media for Fusarium oxysporum. J. Gen. Plant Pathol. 73:342-348.

18. Pasquali, M., Acquadro, A., Balmas, V., Migheli, Q., Lodovica, G. M., and Garibaldi, A. 2004. Development of PCR primers for a new Fusarium oxysporum pathogenic on Paris daisy (Argyranthemum frutescens L.). Eur. J. Plant Pathol. 110:7-11.

19. Pasquali, M., Dematheis, F., Gullino, M. L., and Garibaldi, A. 2007. Identi- fication of race 1 of Fusarium oxysporum f. sp. lactucae on lettuce by interretrotransposon sequence-characterized amplified region technique. Phytopathology 97:987-996.

20. Southwood, M. J., Viljoen, A., Mostert, G., and McLeod, A. 2011. Molecular identification of two vegetative compatibility groups of Fusarium oxysporum f. sp. cepae. Phytopathology 102:204-213.

21. Suga, H., Hirayama, Y., Morishima, M., Suzuki, T., Kageyama, K., and Hyakumachi, M. 2011. PCR primers for detection of Fusarium oxysporum f. sp. fragariae. Jpn. J. Phytopathol. 77:62. (Abstract in Japanese)

22. Suga, H., Karugia, G. W., Ward, T., Gale, L. R., Tomimura, K., Nakajima, T., Miyasaka, A., Koizumi, S., Kageyama, K., and Hyakumachi, M. 2008 Molecular characterization of the Fusarium graminearum species complex in Japan. Phytopathology 98:159-166.

23. Temporini, E., and VanEtten, H. 2002. Distribution of the pea pathogenicity $(P E P)$ genes in the fungus Nectria haematococca mating population VI. Curr. Genet. 41:107-114.

24. van der Does, H. C., Lievens, B., Claes, L., Houterman, P. M., Cornelissen, B. J. C., and Rep, M. 2008. The presence of a virulence locus discriminates Fusarium oxysporum isolates causing tomato wilt from other isolates. Environ. Microbiol. 10:1475-1485.

25. Winks, B. L., and Williams, Y. N. 1965. A wilt of strawberry caused by a new form of Fusarium oxysporum. Queensl. J. Agric. Anim. Sci. 22:475-479.

26. Zhao, X., Zhen, W., Qi, Y., Liu, X., and Yin, B. 2009. Coordinated effects of root autotoxic substances and Fusarium oxysporum Schl. f. sp. fragariae on the growth and replant disease of strawberry. Front. Agric. China 3:34-39. 